Check for updates

Bogotá, Colombia

lukestephentaylor@gmail.com Cite this as: BMJ 2021;372:n611 http://dx.doi.org/10.1136/bmi.n611 Published: 9 March 2021

\section{Covid-19: Why Peru suffers from one of the highest excess death rates in the world}

\section{Peru was praised for imposing swift pandemic measures early on, so why are its excess deaths so high, asks Luke Taylor}

\section{Luke Taylor freelance journalist}

In March 2020, as the financial pain caused by Peru's national lockdown began to bite, thousands of families fled the capital of Lima for their rural hometowns.

With small children and possessions strapped to their backs they trekked up to hundreds of miles through the Andes to return to their families for shelter and support. By April around 170 ooo Peruvians had requested support from their local government to return home to the countryside. Many had lost their jobs after businesses were closed and residents were ordered to stay at home on 16 March. ${ }^{1}$ Some of those who decided it was better to walk home than stay in the capital were repelled by police, who fired teargas in an attempt to stop them. ${ }^{2}$

Peru's government had acted swiftly, imposing a lockdown just 10 days after its first case was reported. It was hoped that the pain suffered by its citizens would be short term and eventually justified by a victory over the virus. Instead, the mass migration of Peru's families has become symbolic of its failure to understand its people.

"Why did the Ministry of Health not hire buses to get people to certain destinations and pay them to quarantine for two weeks?" asks Valeria Paz-Soldan, who runs public health surveillance programmes in Peru for the US Tulane University. "There was so little consideration for the reality for people who were stuck in the wrong place at the wrong time."

A year on, Peru has the unenviable record of more than 2610 per million excess deaths among its population of 33 million-almost twice that of the US and the most of any large nation. ${ }^{3}$ At the time of writing, the government reported that 47000 Peruvians have died from covid-19 so far-though excess death figures suggest that, because of undertesting, the actual total is closer to 85000 .

\section{Rocky foundations}

The high death toll can be explained in part by the country's weak health system. "For decades we've had an underfunded health system with poor primary care and hospitals that are outdated. By the time the pandemic hit, we had underpaid health professionals and very low numbers of intensive care beds," says Patricia García, Peru's minister of health in 2016-17.

Health expenditure has increased from $4.5 \%$ of gross domestic product (GDP) at the turn of the century to around $5 \%$ today (the Organisation for Economic Co-operation and Development average is $8.8 \%$ of GDP), but it is not enough to compensate for growing health burdens, like obesity, which have added strain to the health system.

Peru has 1656 ICU beds for its population of 33 million people ${ }^{4}$; neighbouring Colombia-where the healthcare system has barely kept up with covid-19 admissions-has around 1800 beds in the capital of Bogota alone, where 8 million reside.

"If you add additional layers of stress to a health system that was already on the brink of collapse, you'll have collapse," says Mateo Prochazka. He is one of several Peruvian epidemiologists who told The $B M J$ that the biggest challenge they faced as medical trainees was freeing up beds in hospitals perennially running at capacity. Covid-19 tipped the system over the edge. Many of the country's excess deaths were likely from people suffering from other illnesses who could not be treated because of the health system's collapse.

\section{Local solutions missing}

Peru also ticks off the checklist of features that have hampered pandemic responses across Latin America: diverse populations and geographies; deep poverty; cramped, multigenerational housing; and a lack of laboratories for testing. The list is long and, in most cases, more severe in Peru than its regional neighbours.

These contextual factors are critical in considering any pandemic control tactics, says García, pointing to a shortage of water and electricity, a lack of trust in the government after years of political instability, and a labour market that relies on informal employment. The fact that around three quarters of people work in informal jobs meant they had to risk either contracting covid-19 or going hungry during lockdown. Like in other South American countries, most people eventually opted for the former.

Cultural norms draw people together, increasing chances of transmission. Most Peruvians shop daily. Stocking up with a weekly shop would mean breaking a lifelong habit. It's also impossible for the $40 \%$ who do not have a refrigerator. ${ }^{5}$ As a result, markets quickly became a major vector of the disease. As many as $86 \%$ of people in Lima's markets tested positive during the first wave of cases in May 2020. ${ }^{6}$ Then-president Martin Vizcarra acknowledged the crisis but did not shut markets down because of the need to supply food.

On 9 November 2020, Vizcarra became the latest president to be ejected from office in a political storm, which added to Peru's gargantuan challenge of 
reining in the virus. The country has since had three new presidents, prompting mass protests.

Still, the government should have done more, public health experts say. From personal protective equipment to food donations, the support has been insufficient, says Paz-Soldan, leaving individuals and private organisations to fill the gaps.

Where the government has been generous in its response it has still failed to deliver. Its decision to allocate $12 \%$ of GDP to individuals and companies that lost income because of lockdown measures was lauded. Income support could have helped people stay at home and flatten the epidemiological curve. But for many it arrived too late as $38 \%$ of Peruvian adults do not have bank accounts. It also caused queues to form outside banks-a new risk of virus transmission.

Food was promised to families on low incomes but was distributed through local municipalities who had no experience in doing so. It, too, arrived slowly, Paz-Soldan says. Yet a system that could have been used as a conduit already existed: comedores populares-low cost restaurants which distribute government donated food with volunteer cooks.

Some experts say that Peru's failure was caused by the expectation that just mirroring containment tactics applied in Europe and North America would stem the spread. "Had each intervention been adapted to context, we may have been able to bend the curve a little bit better than we did," Prochazka says, pointing to the Ebola epidemic in West Africa during 2013-15. Initial tactics there failed because of a Euro-centric response from international organisations sent to help. They didn't consider local culture, such as how traditional funerals involved family washing of the body of the deceased. Once control measures were "adapted to context and grounded in local understandings of disease and these control measures," they were more effective, he says.

At the time of writing, covid-19 cases were once again rising, with hospitals coming under more intense pressure. In much of Lima and nine other regions businesses were under government orders to close and people to work from home, as they had been since 1 February. It gave little information on financial support and cases continue to climb.

The country's first vaccine, China's Sinopharm, was administered on 9 February. But hope has been quickly overshadowed by yet another political scandal. It emerged that ex-president Vizcarra and other public officials, including the ministers of health and foreign affairs, had been given a dose before public vaccination began, prompting the resignation of the country's fourth health minister since the beginning of the pandemic. ${ }^{7}$

"For the most part we are in worse shape than we were a year ago," says Paz-Soldan.

Commissioned, not peer reviewed

Competing interests: I have read and understood BMJ policy on declaration of interests and have no relevant interests to declare.

1 Yacila RC, Turkewitz J. Highways of Peru swell with families fleeing virus. New York Times 30 April 2020. www.nytimes.com/2020/04/30/world/americas/20virus-peru-migration.html

2 Collyns D. Peru: riot police block highway as people attempt to flee amid lockdown. Guardian 20 April 2020. www.theguardian.com/world/2020/apr/20/peru-riot-police-highway-teargascoronavirus-lockdown

3 Tracking covid-19 excess deaths across countries. Economist. www.economist.com/graphic-detail/coronavirus-excess-deaths-tracker

4 Barreto C, Mejia M. Peru's intensive care units at capacity as virus cases surge. Associated Press 11 January 2021. https://apnews.com/article/lima-coronavirus-pandemic-peru-

847fb33c1f5c49ca70b66227f0435e2e
5 Bel PP, Horton J. Coronavirus: What's happening in Peru? BBC News 9 July 2020. www.bbc.co.uk/news/world-latin-america-53150808

6 Collyns D. "Hubs of infection”: how covid-19 spread through Latin America's markets. Guardian 17 May 2020. www.theguardian.com/world/2020/may/17/coronavirus-latin-america-marketsmexico-brazil-peru

7 Peru swears in new health minister after covid vaccine scandal. Al Jazeera 13 February 2021. www.aljazeera.com/news/2021/2/13/peru-swears-in-new-health-minister-after-covid-vaccinescandal

This article is made freely available for use in accordance with BMJ's website terms and conditions for the duration of the covid-19 pandemic or until otherwise determined by BMJ. You may use, download and print the article for any lawful, non-commercial purpose (including text and data mining) provided that all copyright notices and trade marks are retained. 